\title{
Phytotherapy as treatment for anxiety: An alternative to minimize addiction and side effects
}

\author{
Fitoterapia como tratamento da ansiedade: Uma alternativa para minimizar o vício e os \\ efeitos colaterais.
}

\section{La fitoterapia como tratamiento para la ansiedad: Una alternativa para minimizar la adicción y los efectos secundarios.}

Domingos Magno Santos Pereira ${ }^{1 *}$, Paulo Cesar Morales Mayer ${ }^{1}$, Kassyo Lenno Sousa Dantas ${ }^{1}$, Tatielle Gomes Dias ${ }^{1}$, Caio Cesar Nascimento Silva ${ }^{1}$, Milena Sousa Freitas ${ }^{1}$, Sheyrlani Tatiany da Silva ${ }^{1}$, Cristiane Santos Silva e Silva Figueiredo ${ }^{1}$, Caroline Amélia Gonçalves ${ }^{2}$.

\begin{abstract}
Objective: To describe the anxiolytic activity and possible mechanisms of action on the central nervous system of plants found in the region known as legal Amazon in the Brazilian territory. Bibliographic Review: For this, five plants popularly used as tranquilizers and to treat insomnia in the forms of teas and extracts were selected, they are: passion fruit, valerian, chamomile, lemon grass and bay leaf. A bibliographic survey of articles, mainly original research, reporting comparative studies of the anxiolytic effects of each plant against control groups, as well as its possible mechanisms of action on the nervous system through preclinical and clinical studies, was performed. Conclusion: All the selected plants exhibited comparable and even superior anxiolytic effects when compared to classes of drugs such as benzodiazepines, with minimization or elimination of side/adverse effects. In addition, all reviewed studies indicated some involvement of gamma-aminobutyric acid (GABA) receptors activation by plant chemical constituents in anxiolytic action. Due to the minimization of adverse effects and the absence of dependence, herbal medicine appears as an important alternative therapy to treat anxiety disorders.
\end{abstract}

Keyword: Anxiety, Herbal Medicine, Amazon Region.

\section{RESUMO}

Objetivo: Descrever a atividade ansiolítica e os possíveis mecanismos de ação no sistema nervoso central de plantas encontradas na região conhecida como Amazônia legal no território brasileiro. Revisão Bibliográfica: Para isto, foram selecionadas cinco plantas popularmente utilizadas como tranquilizantes e para tratar insônia nas formas de chás e extratos, são elas: maracujá, valeriana, camomila, capim-limão e folha de louro. Foi realizado levantamento bibliográfico de artigos, principalmente originais de pesquisa, relatando estudos comparativos dos efeitos ansiolíticos de cada planta contra grupos controles, bem como seus possíveis mecanismos de ação no sistema nervoso através de estudos pré-clínicos e clínicos. Conclusão: Todas as plantas selecionadas apresentaram efeitos ansiolíticos comparáveis e até superiores quando comparados a classes de fármacos como os benzodiazepínicos, com minimização ou eliminação de efeitos colaterais/adversos. Além disso, todos os estudos revisados indicaram algum envolvimento da ativação de receptores do ácido gama-aminobutírico (GABA) pelos constituintes químicos das plantas na ação ansiolítica. Devido à minimização dos efeitos adversos e à ausência de dependência, a fitoterapia aparece como uma importante terapia alternativa para tratar os transtornos de ansiedade.

Palavras-chave: Ansiedade, Fitoterapia, Região Amazônica.

1Universidade Ceuma - UNICEUMA, Imperatriz-Maranhão. *E-mail: domingos.santos@ceuma.br ${ }^{2}$ Faculdade de Imperatriz - FACIMP Wyden, Imperatriz-Maranhão. 


\section{RESUMEN}

Objetivo: Describir la actividad ansiolítica y los posibles mecanismos de acción sobre el sistema nervioso central de las plantas que se encuentran en la región conocida como la Amazonía legal en el territorio brasileño. Revisión bibliográfica: Para esto, se seleccionaron cinco plantas utilizadas popularmente como tranquilizantes y para tratar el insomnio en forma de tés y extractos, son: maracuyá, valeriana, manzanilla, hierba de limón y laurel. Se realizó un levantamiento bibliográfico de artículos, principalmente investigaciones originales, que informaron estudios comparativos de los efectos ansiolíticos de cada planta contra los grupos de control, así como sus posibles mecanismos de acción sobre el sistema nervioso a través de estudios preclínicos y clínicos. Conclusión: Todas las plantas seleccionadas tuvieron efectos ansiolíticos comparables e incluso superiores en comparación con las clases de medicamentos como las benzodiacepinas, con minimización o eliminación de efectos secundarios/adversos. Además, todos los estudios revisados indicaron cierta participación de la activación del receptor de ácido gamma-aminobutírico (GABA) por los componentes químicos de la planta en la acción ansiolítica. Debido a la minimización de los efectos adversos y la ausencia de dependencia, la medicina herbal aparece como una terapia alternativa importante para tratar los trastornos de ansiedad.

Palabra clave: Ansiedad, Fitoterapia, Región amazónica.

\section{INTRODUCTION}

Anxiety can be defined as an "alert system" present in most species of animals, including man. It is characterized by natural anticipation in relation to something that has not yet happened, having as main symptoms, concern, restlessness and acceleration of the heartbeats. Despite being necessary for a good performance of daily activities and self-preservation, anxiety can become a pathological state when the feeling of concern is excessive and unrelated to something specific such as an object or a situation (NESS RM, 2015). In this case, what differentiates the normal state from the pathological one is the intensity, frequency and duration with which the symptoms are triggered.

People suffering from pathological anxiety live with disease outbreaks that may vary in intensity and duration. On the other hand, generalized anxiety cases tend to be persistent and aggravated, compromising the individual's social life, which may present low productivity and interest in their daily activities such as working and living with family and friends. In addition, the presence of some anxiety symptoms is correlated with multiple anxiety disorders, such as social phobia, posttraumatic stress, and panic or even other mental illnesses like depression (BANDELOW B, 2015 and MICHAELIS S, 2015).

The disease is considered the most common psychiatric disorder in the world population. It is estimated that $9.3 \%$ of the Brazilian individuals suffer from some anxiety disorder, corresponding to the highest worldwide index. However, it is important to note that not only depression is correlated to the increase in suicide rates, but also generalized anxiety (WHO, 2017).

The conventional treatment for anxiety is based on the use of drugs belonging to psychoactive pharmacological classes such as benzodiazepines, barbiturates and modulators of the gamma-aminobutyric acid (GABA) receptors; drugs, which cause a wide range of side effects, such as ataxia, dizziness, sedation, and memory loss, besides being ineffective in some cases (STEWART AM, et al., 2015). Psychotherapy is also highly prescribed, since it assists in the individual's adaptation on how to deal with the stressful events of their daily life; however, pharmacological drugs are widely used for the reestablishment of the normal brain chemical composition, since these patients present levels of some neurotransmitters, such as noradrenaline and serotonin, compromised (STRAWN JR, et al., 2018).

In view of the need to develop new therapeutic interventions, taking into account the increasing cases of the disease, and the high number of side effects of the conventional pharmacological treatments (which are not always effective), this study aimed to describe the anxiolytic activity of some plants found in legal Amazon region - but not all they being native - and their possible mechanism of action. 


\section{LITERATURE REVIEW}

\section{Phytotherapy and society}

Medicinal plants have been used since the dawn of mankind. They are directly related to the maintenance of human health in all eras and in many regions still represent the only alternative to treat several pathologies. It is estimated that $80 \%$ of the world population has already used some plant material to treat biological disorders (AGRA M, et al., 2007). Among the main forms of use for therapeutic purposes we can mention teas and syrups for oral ingestion and topical treatments in forms of infusion and compresses. It is important to note that all constituents of the plant are used in preparation of these administration forms, this is, leaves, roots, fruits, pulps, seeds, peels, etc. (FARHADI F, et al., 2016).

The use of medicinal plants has been gaining more and more space in Brazilian society since it is well known that Brazil has one of the richest natural resources in the world. The region called legal Amazon, comprising the northern states (Acre, Amapá, Amazonas, Pará, Rondônia, Roraima and Tocantins), part of Mato Grosso (Center-West Region) and most of the state of Maranhão in Northeast (HUBBELL SP, et al., 2008), is one of the main areas where these plants can be found and grow. The presence of these resources - all types of plant life - through biotechnological techniques, allows the development of new drugs and herbal medicines sold in capsule forms and parts of dehydrated plants.

The variety of diseases treated through phytotherapy is relatively high and the efficiency rates are increasingly demonstrated through scientific experiments. Plant-derived products are daily used to combat infectious (SILVA BCJ et al., 2017), inflammatory (KIM HP, et al., 2017), gastrointestinal (CHOUDHURY PR, et al., 2015) and mental diseases such as depression and anxiety (FARAHANI MS et al., 2015). Among the many species found in Brazilian flora, we described five that, although not all of them being native from Legal Amazon, they can be easily found throughout the region, since they adapt perfectly to the tropical climate and are widely known; they are: passion fruit, valerian, camomile, lemongrass and bay leaf, discussed in next section.

\section{Passion fruit (Passiflora edulis)}

It is a plant belonging to a large family of Passifloraceae (at about 400 species) (KIM HP, et al., 2017), whose anxiolytic effect has already been demonstrated in several studies. The most used parts of the plant are fruits (shells and pulp) and flowers (SOUZA MM et al., 2008) consumed mainly in forms of juices - in case of pulps - and teas, for insomnia and as natural tranquilizer (GUERRERO FA and MEDINA GM, 2017). Barbosa PR et al., (2008) evaluated, in rats, the anxiolytic activity of two species of Passiflora (alata and edulis) in comparison to diazepam-treated groups; results showed that both plants exhibited anxiolytic effect similar to diazepam controls. In addition, phytochemical analysis revealed high concentration of flavonoids in aqueous extract of $P$. edulis, almost twice higher when compared to $P$. alata levels. Wasowski $C$ and Marder $M(2012)$, in the study "Flavonoids as GABA A receptor ligands: the whole story?", demonstrated that many flavonoids, including some present in plants of the genus Passiflora sp. exhibit anxiolytic activity through interaction with gamma-aminobutyric acid (GABA) receptors expressed in central nervous system (CNS), possibly inhibiting the release of glutamate - excitatory neurotransmitter - reducing the activity of brain regions responsible for the symptoms of anxiety (NUSS P, et al., 2015).

Therefore, the components present in passion fruit are suggested as anxiolytics by interfering in cell signalling, increasing inhibitory responses in CNS. Moreover, GABA receptors mediate several mechanisms of action of herbal medicines and medicinal plants.

\section{Valerian (Valeriana officinalis)}

Another alternative therapy to treat anxiety is valerian, which belongs to the Valerianaceae family and is widely used in folk medicine to treat insomnia, restlessness and anxiety (JACOBS B P et al., 2005). The plant has already been suggested to treat several diseases because of its antimicrobial (KHUDA F, et al., 2012), anti-inflammatory (NEAMATI A, et al., 2014) and antioxidant (SUDATI JH et al., 2009) activities. Still, studies have demonstrated antidepressant and anxiolytic properties (NEAMATI A, et al., 2014). Murphy K et al. (2010) 
investigated the potential of valerian to treat rats with anxiety induced by anxiogenic situations (for a better understanding of these experimental models, read: BOURIN M, 2015). Their findings confirmed the anxiolytic effect of valerian, through comparison with diazepam-treated rats.

In order to better understand the mechanisms of action, other studies show that the plant presents valeric acid in its composition (VALLE-MOJICA D, et al., 2011), a GABA-A receptor agonist, therefore, some researchers suggest that the anxiolytic effect of valerian is similar to benzodiazepine drugs, potentially acting at allosteric sites of GABA-related receptors (BECKER A, et al., 2014).

\section{Chamomile (Matricaria chamomilla)}

It is a well known plant used in popular medicine in form of tea, especially for insomnia and as a tranquilizing agent, previous studies have already demonstrated that chamomile presents anti-inflammatory (BHASKARAN $\mathrm{N}$, et al., 2010) and anxiolytic (CHANG SM, CHEN CH, 2016) activities. It is widely used in topical form to soothe the skin and attenuate redness caused by external aggressions such as those caused by sun and air pollutants (LEE SH, et al., 2010).

A recent study published by Mao JJ et al. (2014) evaluated the anxiolytic effect of chamomile in volunteer patients diagnosed with generalized anxiety treated with chamomile and placebo capsules; results demonstrated that chamomile significantly reduced anxiety-related parameters evaluated against placebotreated patients.

For a better understanding of how the chemical compounds present in the plant act, Srivastava JK et al. (2010) reported that extracts are rich in terpenoids and flavonoids, which are pointed as chemical classes related to therapeutic effects. The mechanism of action of chamomile is still unclear. However, some studies already showed that anxiolytic effect occurs through the interference of its compounds in inhibitory signalling in CNS through interaction with inhibitory receptors (SRIVASTAVA JK, et al., 2010).

LEE SH, et al. (2010) carried out a study called "Short-term open-label chamomile therapy of moderate to severe generalized anxiety disorder" where they discussed the mechanism of action of chamomile constituents and attributed their anxiolytics effects to interaction with gamma-aminobutyric acid (GABA) receptors, producing inhibitory responses in the central nervous system.

\section{Lemongrass (Cymbopogon citratus)}

It is a plant widely used in form of tea and as natural tranquilizer. Several studies report the plant or its pure essential oil to present therapeutic activities because of its antimicrobial (DE SILVA BCJ, et al., 2017), antiinflammatory (BOUKHATEM MN, et al., 2014) and antioxidant (KOH PH, et al., 2012) effects.

Additionally, studies found anti-depressant (UMUKORO S, et al., 2017) and anxiolytic (GOES TC, et al., 2015) properties of the compounds contained in vegetable or extracted essential oil. The anxiolytic effect of lemongrass has been demonstrated through several scientific studies involving human volunteers and animals (DUBEY MN and SHARMA MA, 2018) and its therapeutic use is suggested by several health professionals; it is important to emphasize that lemongrass presents a high level of safety in respect to its toxicity (LEITE JR, et al., 1996).

A recently published clinical study conducted by Goes TC et al., (2015) investigated the natural response of healthy volunteers treated with lemongrass essential oil in responding to anxiogenic situations, against a control group (healthy volunteers treated with water). Results showed that lemongrass-treated volunteers exhibited reduced anxiogenic responses to the tested stimuli, when compared with those placebo-treated ones. Therefore, authors suggest the use of lemongrass as a possible therapy to treat symptoms of stress and anxiety, although clearly exposing the need for further studies to fully elucidate the mechanisms of action.

A better perspective on the mechanisms of action of the constituents of the plant can be found in Costa $C$ et al. (2011), where it was evaluated the treatment of mice with lemongrass essential oil and selective antagonists for benzodiazepine (drug: flumazemil) and 5-HT receptors (serotonin; drug: WAY100635), submitted to situations that generate anxiety and depression. Results showed that only mice treated with 
WAY100635 and essential oil of Cymbopogon citratus exhibited anxiety frames reverted, hence, researchers involved in the study suggested the compounds of this essential oil present mechanism of action via activation of GABA receptors.

\section{Bay leaf (Aniba riparia)}

This plant comprises about 40 species distributed in several regions such as Amazonia, Andes, Guianas and Venezuela. It is popularly known as Sweet bay, Grecian laurel, true laurel or simply laurel and possess chartaceous leaves, matte on both sides. In its bark and stem were found flavonoids, benzoyl benzoates and benzaldehydes and in its unripen fruit some alkaloids, which attribute to it the therapeutic effects, such as antimicrobial activity against gram-positive bacteria and anti-inflammatory properties (CATAO RMR, et al., 2010). Moreover, in vitro and behavioural studies in animals have shown these alkaloids as antidepressant, analgesic and anxiolytic agents being also related to the signalling via GABA system (TEIXEIRA, et al., 2013).

Its anxiolytic effects were devoid of sedative or muscle relaxant effects, unlike the classic benzodiazepines, thus, being classified as strong candidates for synthesis of new drugs to treat depression and anxiety (NUNES GBL, et al., 2013).

\section{CONCLUSION}

The use of herbal remedies as a coadjutant in the treatment of anxiety symptoms is a practice that has been gaining supporters. The minimization and even absence of debilitating side effects of the use of benzodiazepines and the non-production of dependence are two of the factors that justify the search for this alternative. Although the present study was not a comprehensive and thorough review of the theme, for the five plants studied, comparative studies attested its anxiolytic activities. The observed effects were comparable or even higher than those obtained with the use of traditional benzodiazepines. Although not all of the reviewed studies have given adequate emphasis to side effects, those which measured it did not show drowsiness or impairment of the motor activity, typically found in traditional psychoactive medications. Despite the promising results and the popular use of the plants studied here for relieving anxiety symptoms, it is worth noting that many of these studies are still pre-clinical, performed with animals, or in controlled situations, which means that despite the safety and low toxicity of these plants, their effects still need to be properly tested in natural settings for humans.

\section{REFERENCES}

1. AGRA MF, et al. Synopsis of the plants known as medicinal and poisonous in Northeast of Brazil. Revista Brasileira de Farmacognosia, 2007; 17(1): 114-140.

2. BANDELOW B, MICHAELIS S. Epidemiology of anxiety disorders in the 21st century. Dialogues in clinical neuroscience, 2015; 17(3): 327-335.

3. BARBOSA PR, et al. The aqueous extracts of Passiflora alata and Passiflora edulis reduce anxiety-related behaviors without affecting memory process in rats. Journal of medicinal food, 2010; 11(2): 282-288.

4. BECKER A, et al. The anxiolytic effects of a Valerian extract is based on valerenic acid. BMC complementary and alternative medicine, 2014; 14(1): 267.

5. BHASKARAN N, et al. Chamomile: an anti-inflammatory agent inhibits inducible nitric oxide synthase expression by blocking RelA/p65 activity. International journal of molecular medicine, 2010; 26(6): 935-940.

6. BOUKHATEM MN, et al. Lemon grass (Cymbopogon citratus) essential oil as a potent anti-inflammatory and antifungal drugs. Libyan Journal of Medicine, 2014; 9(1): 25431.

7. BOURIN M. Animal models for screening anxiolytic-like drugs: a perspective. Dialogues in Clinical Neuroscience, 2015; 173: 295-303.

8. CATAO RMR, et al. Avaliação da atividade antimicrobiana e efeitos biológicos de riparinas sobre eliminação de resistência a drogas em amostras de Staphylococcus aureus. Revista Brasileira de Análises Clínicas, 2010; 4: 9-14.

9. CHANG SM, CHEN CH. Effects of an intervention with drinking chamomile tea on sleep quality and depression in sleep disturbed postnatal women: a randomized controlled trial. Journal of Advanced Nursing, 2016; 72(2): $306-315$.

10. CHOUDHURY PR, et al. Plant utilization against digestive system disorder in Southern Assam, India. Journal of ethnopharmacology, 2015; 175: 192-197.

11. COSTA C, et al. The GABAergic system contributes to the anxiolytic-like effect of essential oil from Cymbopogon citratus (lemongrass). Journal of ethnopharmacology, 2011; 137(1): 828-836. 
12. DE SILVA BCJ, et al. Antimicrobial property of lemongrass (Cymbopogon citratus) oil against pathogenic bacteria isolated from pet turtles. Laboratory animal research, 2017; 33(2): 84-91.

13. DUBEY MN, SHARMA MA. Comparative study of ethanolic extract of lemon grass \& lemon peels by aroma therapy on stress induced anxiety on mice. International Journal of Pharmaceutical Archive, 2018; 7(6): 1-12.

14. FARAHANI MS, et al. Plant-derived natural medicines for the management of depression: an overview of mechanisms of action. Reviews in the Neurosciences, 2018; 26(3): 305-321.

15. FARHADI K, et al. Determination of phenolic compounds content and antioxidant activity in skin, pulp, seed, cane and leaf of five native grape cultivars in West Azerbaijan province, Iran. Food chemistry, 2016; 199: 847-855.

16. GOES TC, et al. Effect of lemongrass aroma on experimental anxiety in humans. The Journal of Alternative and Complementary Medicine, 2015; 21(12): 766-773.

17. GUERRERO FA, MEDINA GM. Effect of a medicinal plant (Passiflora incarnata L) on sleep. Sleep Science,2017; 10(3): 96.

18. HUBBELL SP, et al. How many tree species are there in the Amazon and how many of them will go extinct. Proceedings of the National Academy of Sciences, 2008; 105(n. Supplement 1): 11498-11504.

19. JACOBS BP, et al. An internet-based randomized, placebo-controlled trial of kava and valerian for anxiety and insomnia. Medicine, 2005; 84(4): 197-207.

20. KHUDA F, et al. Antimicrobial and anti-inflammatory activities of leaf extract of Valeriana wallichii DC. Pakistan Journal of Pharmaceutical Sciences, 2012; 25(4): 715-719.

21. KIM HP, et al. Therapeutic potential of medicinal plants and their constituents on lung inflammatory disorders. Biomolecules \& therapeutics, 2017; 25(2): 91.

22. $\mathrm{KOH} \mathrm{PH}$, et al. Antioxidant potential of Cymbopogon citratus extract: alleviation of carbon tetrachloride-induced hepatic oxidative stress and toxicity. Human \& experimental toxicology, 2012; 31(1): 81-91.

23. LEE SH. Effect of German chamomile oil application on alleviating atopic dermatitis-like immune alterations in mice. Journal of veterinary science, $2010 ; 11(1): 35-41$.

24. LEITE JR, et al. Pharmacology of lemongrass (Cymbopogon citratus Stapf). III. Assessment of eventual toxic, hypnotic and anxiolytic effects on humans. Journal of Ethnopharmacology, 1986; 17(1): 75-83.

25. MAO JJ, et al. Long-term chamomile therapy of generalized anxiety disorder: a study protocol for a randomized, double-blind, placebo-controlled trial. Journal of Clinical Trials, 2014; 4(5):188.

26. MURPHY K, et al. Valeriana officinalis root extracts have potent anxiolytic effects in laboratory rats. Phytomedicine, 2010; 17(8-9): 674-678.

27. NEAMATI A, et al. The effects of Valeriana officinalis L. hydro-alcoholic extract on depression like behavior in ovalbumin sensitized rats. Journal of pharmacy \& bioallied sciences, 2014; 6(2): 97.

28. NESSE RM. Evolutionary Psychology and Mental Health. In D. M. Buss (Ed.), The Handbook of Evolutionary Psychology (pp. 903-927). Hoboken, NJ, USA: John Wiley \& Sons, Inc, 2015.

29. NUNES GBL, et al. Prospecção científica e tecnológica da Aniba riparia (Nees) Mez (Lauraceae). Cadernos de Prospecção, 2013; 6(4): 447-458.

30. NUSS P. Anxiety disorders and GABA neurotransmission: a disturbance of modulation. Neuropsychiatric disease and treatment, 2015; 11: 165.

31. SOUZA MM, et al. Cytogenetic studies in some species of Passiflora L.(Passifloraceae): a review emphasizing Brazilian species. Brazilian Archives of Biology and Technology, 2008; 51(2):247-258.

32. SRIVASTAVA JK, et al. S. Chamomile: a herbal medicine of the past with a bright future. Molecular medicine reports, 2010; 3(6): 895-901.

33. STEWART AM, et al. The failure of anxiolytic therapies in early clinical trials: what needs to be done. Expert Opinion on Investigational Drugs, 2015; 24(4): 543-556.

34. STRAWN JR, et al. Pharmacotherapy for generalized anxiety disorder in adults and pediatric patients: an evidencebased treatment review, Expert Opin Pharmacother, 2018; 19(10): 1057-1070.

35. SUDATI, JH, et al. In vitro antioxidant activity of Valeriana officinalis against different neurotoxic agents. Neurochemical research, 2009; 34(8): 1372, 2009.

36. TEIXEIRA CP, et al. Antidepressant-like effect of riparin II from Aniba riparia in mice: evidence for the involvement of the monoaminergic system. Fundam Clin Pharmacol., 2013; 27(2): 129-37.

37. UMUKORO S, et al. Evidence for the Involvement of Monoaminergic Pathways in the Antidepressant-Like Activity of Cymbopogon citratus in Mice. Drug Research, 2017; 67(7): 419-424.

38. VALLE-MOJICA D, et al. Selective interactions of Valeriana officinalis extracts and valerenic acid with [3H] glutamate binding to rat synaptic membranes. Evidence-based Complementary and Alternative Medicine, 2011;2011.

39. WASOWSKI C, MARDER M. Flavonoids as GABAA receptor ligands: the whole story? Journal of experimental pharmacology, 2012; 4: 9-24.

40. WORLD HEALTH ORGANIZATION. Depression and Other Common Mental Disorders: Global Health Estimates. Geneva: World Health Organization. 2017. 